San Jose State University

SJSU ScholarWorks

Master's Theses

Master's Theses and Graduate Research

1996

\title{
Single-nest exclosures to protect endangered California least terns from off-highway vehicle traffic
}

Robert K. Burton

San Jose State University

Follow this and additional works at: https://scholarworks.sjsu.edu/etd_theses

\section{Recommended Citation}

Burton, Robert K., "Single-nest exclosures to protect endangered California least terns from off-highway vehicle traffic" (1996). Master's Theses. 1299.

DOI: https://doi.org/10.31979/etd.tyz8-ttfk

https://scholarworks.sjsu.edu/etd_theses/1299

This Thesis is brought to you for free and open access by the Master's Theses and Graduate Research at SJSU ScholarWorks. It has been accepted for inclusion in Master's Theses by an authorized administrator of SJSU ScholarWorks. For more information, please contact scholarworks@sjsu.edu. 


\section{INFORMATION TO USERS}

This manuscript has been reproduced from the microfilm master. UMI films the text directly from the original or copy submitted. Thus, some thesis and dissertation copies are in typewriter face, while others may be from any type of computer printer.

The quality of this reproduction is dependent upon the quality of the copy submitted. Broken or indistinct print, colored or poor quality illustrations and photographs, print bleedthrough, substandard margins, and improper alignment can adversely affect reproduction.

In the unlikely event that the author did not send UMI a complete manuscript and there are missing pages, these will be noted. Also, if unauthorized copyright material had to be removed, a note will indicate the deletion.

Oversize materials (e.g., maps, drawings, charts) are reproduced by sectioning the original, beginning at the upper left-hand comer and continuing from left to right in equal sections with small overlaps. Each original is also photographed in one exposure and is included in reduced form at the back of the book.

Photographs included in the original manuscript have been reproduced xerographically in this copy. Higher quality $6 " \mathrm{x} 9$ " black and white photographic prints are available for any photographs or illustrations appearing in this copy for an additional charge. Contact UMI directly to order.

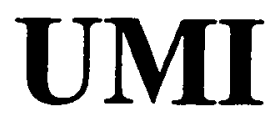

A Bell \& Howell Information Company 



\title{
SINGLE-MEST EXCLOSURES TO PROTECT BNDANGERED CAIIFORMIA IEAST TERNG \\ FROX OFT-BIGHWAY VEEICLE TRAFFIC
}

\author{
A Thesis \\ Presented to \\ The Faculty of the Department of Biological Sciences \\ San Jose State University \\ In Partial Fulfillment \\ of the Requirements for the Degree \\ Master of Arts
}

By

Robert $\mathrm{K}$. Burton

August 1996 
UMI Number: 1381410

UMI Microform 1381410

Copyright 1996, by UMI Company. All rights reserved.

This microform edition is protected against unauthorized copying under Title 17, United States Code.

\section{UMI \\ 300 North Zeeb Road \\ Ann Arbor, MI 48103}


(C) 1996

Robert Kevin Burton

All Rights Reserved 


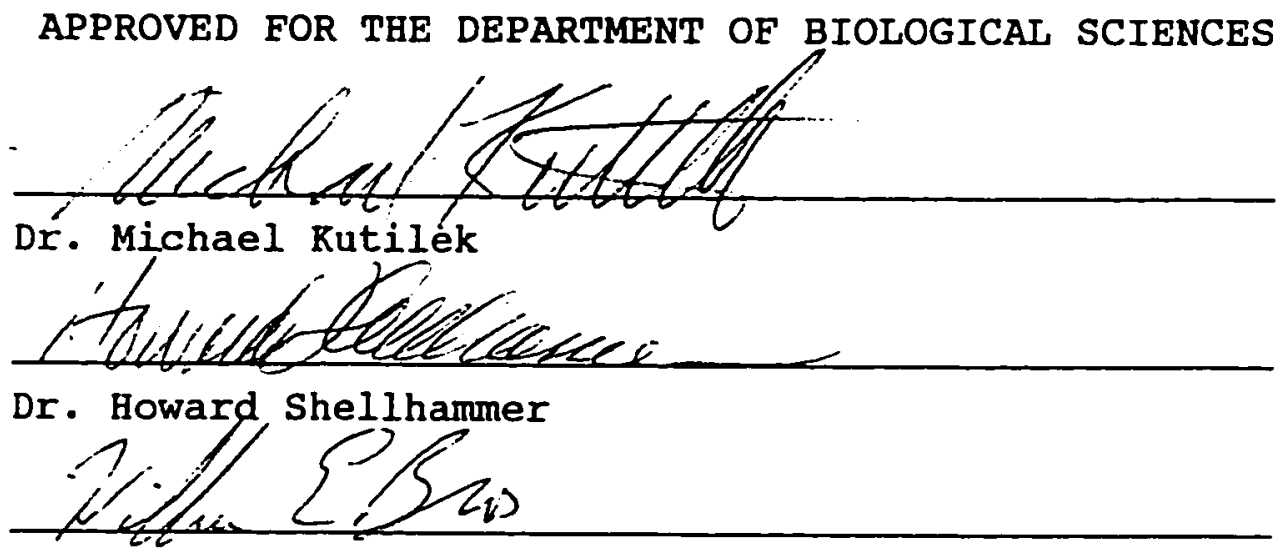

Dr. William Bros

APPROVED FOR THE UNIVERSITY

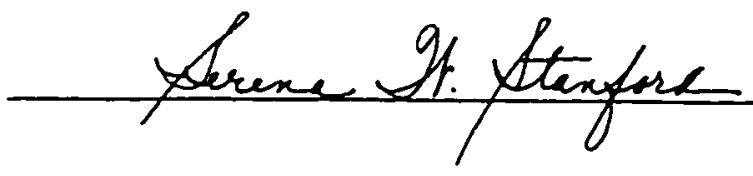




\begin{abstract}
SMALL SINGLE-NEST EXCLOSURES TO PROTECT ENDANGERED CALIFORNIA LEAST TERNS EROM OFF-HIGHWAY VEHICLE TRAFEIC
\end{abstract}

By Robert $K$. Burton

In 1991-1992 I constructed 20.4 to $30 \mathrm{~m}$ diameter fenced exclosures around endangered California Least Tern (Sterna antillarum browni) nests at Pismo Dunes State Vehicular Recreation Area in California. These single-nest exclosures provided effective protection for both adult birds and nests from the direct impacts related to off-highway vehicle recreational activities. As the California Least Tern population recovers, colonization of new nesting sites will continue. The use of single-nest exclosures can provide managers with an effective means for protecting small nesting colonies from a variety of impacts until long-term conservation and management strategies can be developed. 
This thesis is dedicated to

my parents,

Katie and Robbie, and all of the other teachers in my life. 


\section{ACKNOWLEDGEMENTS}

Many people have made very significant contributions towards this project and I thank all of them. I particularly thank Michael Kutilek for being an extraordinary guide, teacher, and friend and for giving me the latitude to develop more fully as a scientist. I thank Howard Shellhammer and Bill Bros for their openness and their willingness to share their insights and thinking into the greater problems we attempt to resolve as conservation biologists.

I would also like to extend my thanks and gratitude to the entire staff at Pismo Dunes and Pismo Dunes State Vehicular Recreation Area for their relentless commitment to this work and for their enthusiasm. In particular I thank Don Patton, Ken Anderson, and Shana Watkins. It is my fortune to have had the opportunity to work with this fine a group of people. 
TABLE OF CONTENTS

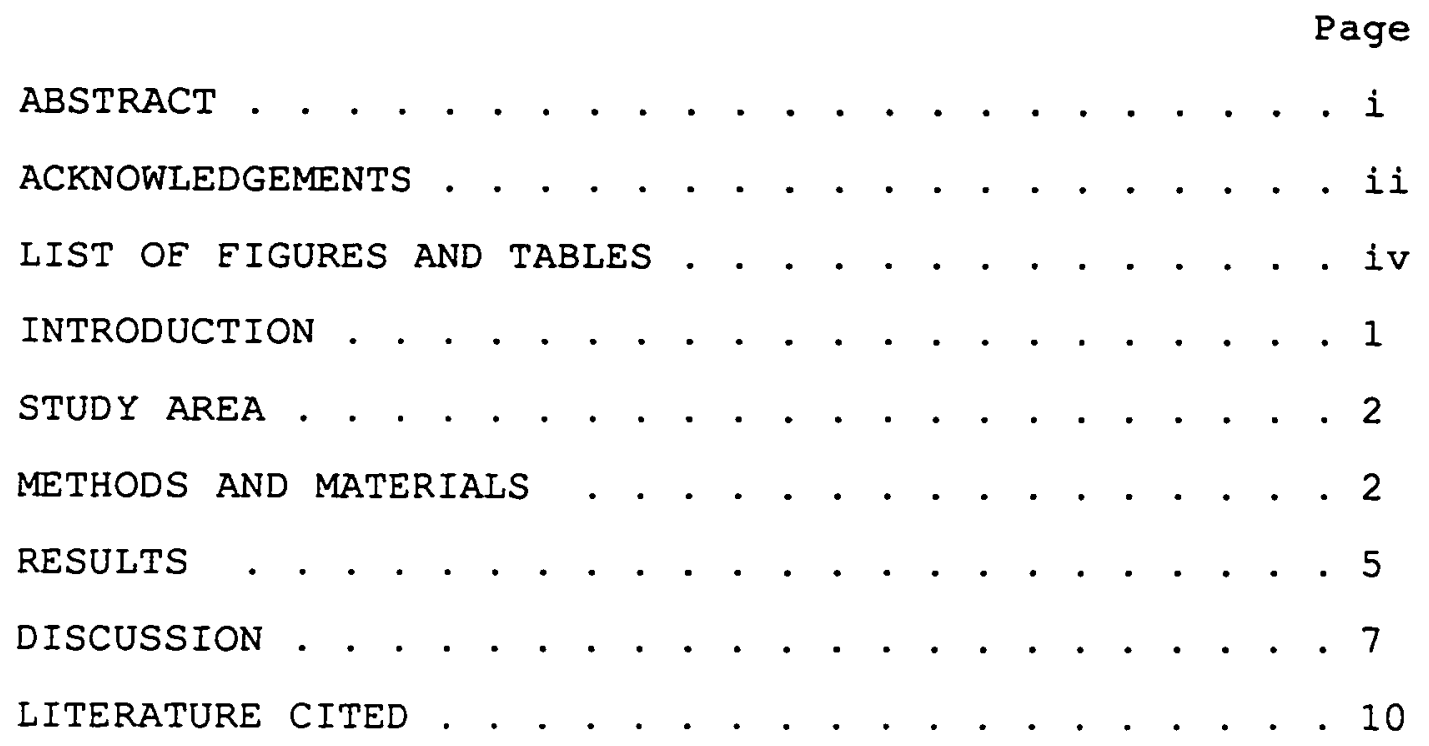




\section{IIST OE FIGURES AND TABLES}

Page

Figure 1. Single nest exclosure used to protect nesting California Least Terns from off-highway vehicle traffic . . . . . . . . . . . . . . . . 4

Table 1. Summary of single-nest exclosure use for the protection of nesting California Least Terns at Pismo Dunes State Vehicular Recreation Area, San Luis Obispo County, Calif. 1 April to 1 September, 1991-1992 . . . . . . . . . . . . . . . . . . 8 


\section{INTRODUCTION}

The California Least Tern (Sterna antillarum browni) is a ground nesting seabird historically found along the Pacific Coast from Baja California to Monterey Bay California (Grinnel 1928). Loss of habitat to development and recreation and disturbance of nesting and feeding grounds has resulted in substantial declines in this subspecies following World War II (Atwood and Minsky 1983, U.S. Fish and Wildlife Service 1980). From 1973 to 1975, the California breeding population was estimated at around 600 pairs (Bender 1974a, 1974b, Massey 1975). The subspecies Sabrowni is designated endangered by both the California Department of Fish and Game (1976) and the U.S. Fish and Wildlife Service (1976).

The open coastal dunes used as nesting habitat by this species have been attractive sites for off-highway vehicle (OHV) recreation enthusiasts. OHV recreation has been identified as a major impact affecting nesting Least Terns at sites throughout the U.S. and Mexico (Blodget 1978, Burger 1989, Carvacho et al. 1989, Gochfield 1983, U.S. Fish and Wildlife Service 1980).

In this paper I describe a small single-nest exclosure designed to protect nesting Least Terns from OHV traffic. Though small single-nest exclosures have been effectively used to reduce nest predation of shorebirds (Rimmer and 
Deblinger 1990), their application to Least Terns or as a deterrent to OHV traffic has not been previously described. This technique can provide effective protection from OHV traffic until more comprehensive management plans are developed.

\section{STUDY AREA}

I conducted field work at Pismo Dunes State Vehicular Recreation Area (PDSVRA) in San Luis Obispo County, California. PDSVRA is 1 of 5 OHV recreation areas managed by the California Department of Parks and Recreation off-Highway Motor Vehicle Recreation Division.

PDSVRA includes 1075 ha of beach and coastal dunes comprised of large expanses of open sand interspersed with fenced areas of vegetation dominated by arroyo willow (Salix lasidepis) and European beach grass (Ammophila arenaria). Several freshwater lakes and creeks found beyond the perimeter of the OHV riding area act as feeding sites for Least Terns. Annual visitation at PDSVRA exceeds 1,000,000 people of which about half engage in motorized vehicle recreation. 


\section{METHODS AND MATERIAIS}

I surveyed the beach and dunes from 1 April to 1 September of 1991 and 1992 to locate Least Tern nests in areas used for OHV recreation. When a nest was located, I remained nearby and observed the adult birds while redirecting vehicle traffic until an exclosure fence could be built.

Nest exclosures were circular in design ranging in diameter from 20.4 to $30 \mathrm{~m}$ (Fig. 1). This size exclosure allowed birds to readily approach and leave the nest from the air. The circular fence was stable without the need for additional support structures such as wood posts or braces. Exclosure fences were constructed with $1.8 \mathrm{~m}$ steel t-stakes, placed at $3 \mathrm{~m}$ intervals, and $1.2 \mathrm{~m}$ wide steel rolled fencing. The large rectangular mesh increased in size from $7.5 \mathrm{~cm} \times 35$ $\mathrm{cm}$ at the bottom to $20 \mathrm{~cm} \times 35 \mathrm{~cm}$ at the top of the fence. Arched terra cotta roof tiles were placed inside each exclosure to provide cover for chicks. Two or 3 people were able to construct an exclosure in approximately 10-15 minutes.

Following the construction of the exclosure, I continued observation of the nest for several hours to look for any immediate disturbance of normal nesting behaviors caused by the fence or fence-building activities. Nests were monitored 
for a minimum of 3 days each week during the breeding season to gather information on breeding success, causes of nest failure, impacts of OHV traffic, and impacts resulting from the use of exclosures. 


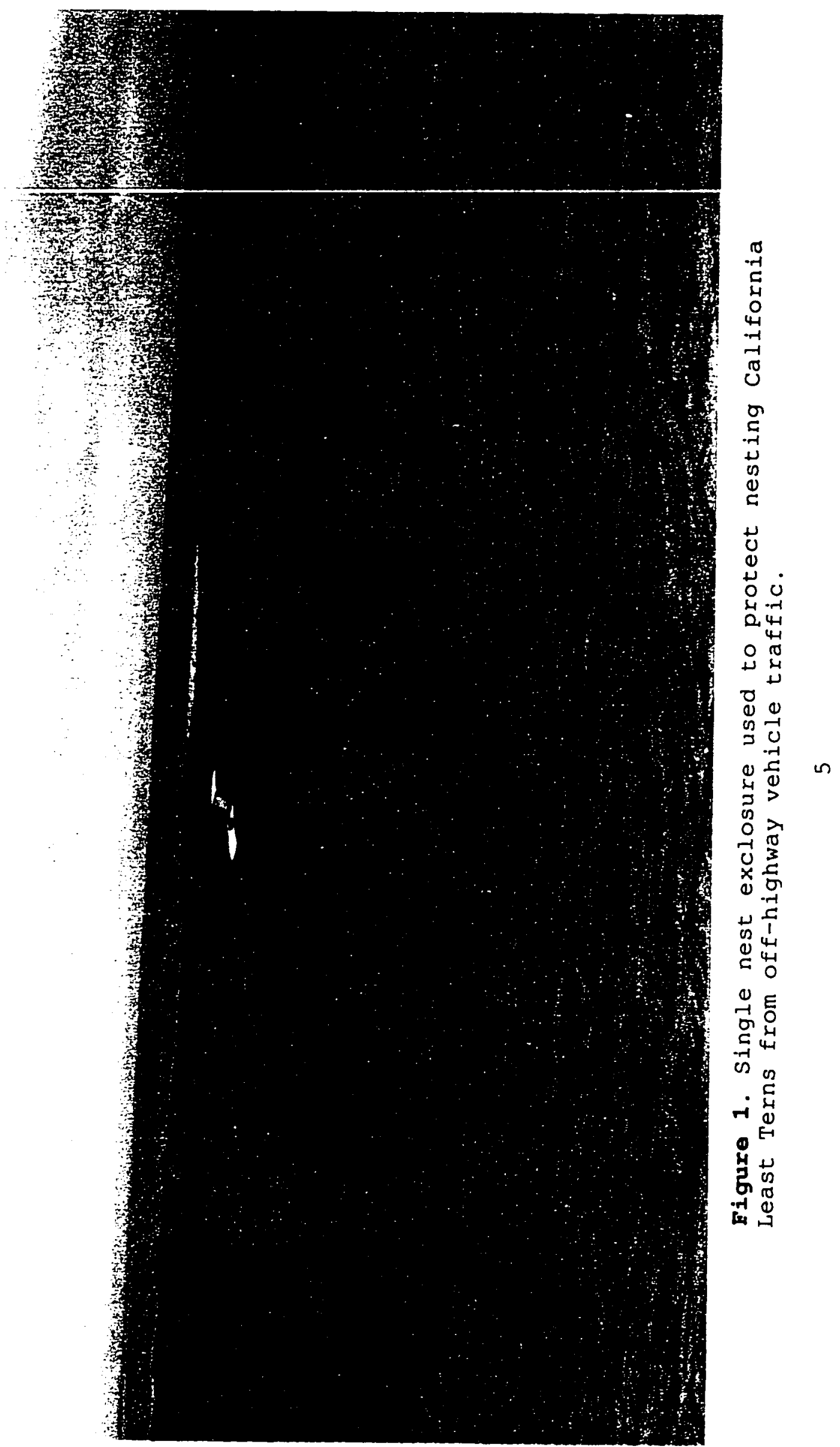




\section{RESUITS}

Six Least Tern nests were distributed over an area of about 2 ha within the OHV riding area in 1990. The nests were protected with a single large, fenced exclosure. In 1991, there were 6 nests in the OHV riding area. A single large exclosure was impractical for these nests because they were distributed over a large area (5-7 ha). Therefore, 5 of the 6 nests were protected with small single-nest exclosures. In 1992, 4 nests were protected with single-nest exclosures.

Of the 9 nests for which I built exclosures, 1 was abandoned immediately and a second was abandoned 2-5 days after construction of the exclosure (Table 1). Both of these nests were incomplete; each contained 1 egg which the adult birds were not incubating at the time the exclosure was built. When exclosures were built around nests where adults were incubating a full clutch, the birds rarely left the vicinity; in most cases the birds returned to the nest before the fence was completed.

There were no nesting failures resulting from the direct impacts of OHV recreational activities at nests for which exclosures where built. Once a nest was protected with an exclosure, the adult birds seem undisturbed by most vehicle traffic. I regularly observed vehicles pass within $10 \mathrm{~m}$ of exclosures without flushing the adult birds. 
Table 1. Summary of single-nest exclosure use for the protection of nesting California Least Terns at Pismo Dunes State Vehicular Recreation Area, San Luis Obispo County, Calif. 1 April to 1 September, 1991-1992.

$\begin{array}{lll}\text { Nest } & \text { Year Action Taken and Nesting Results } \\ \text { Number }\end{array}$

\begin{tabular}{|c|c|c|}
\hline 1 & 1991 & $\begin{array}{l}3 \text { eggs in nest protected with single-nest } \\
\text { exclosure; } 2 \text { chicks hatched and were } \\
\text { confirmed to have fledged. }\end{array}$ \\
\hline 2 & 1991 & $\begin{array}{l}1 \text { egg in nest destroyed by off-highway } \\
\text { vehicle before an exclosure could be } \\
\text { built. }\end{array}$ \\
\hline 3 & 1991 & $\begin{array}{l}1 \text { egg in nest abandoned following } \\
\text { construction of a single-nest exclosure. }\end{array}$ \\
\hline 4 & 1991 & $\begin{array}{l}2 \text { eggs in nest protected with a } \\
\text { single-nest exclosure; } 2 \text { chicks hatched } \\
\text { and were believed to have fledged. }\end{array}$ \\
\hline 5 & 1991 & $\begin{array}{l}1 \text { egg in nest abandoned } 2-5 \text { days after } \\
\text { construction of a single-nest exclosure. }\end{array}$ \\
\hline 6 & 1991 & $\begin{array}{l}2 \text { eggs in nest protected with a } \\
\text { single-nest exclosure; destroyed by high } \\
\text { winds and blowing sand. }\end{array}$ \\
\hline 7 & 1992 & $\begin{array}{l}2 \text { eggs in nest protected with a } \\
\text { single-nest exclosure; destroyed by high } \\
\text { winds and blowing sand. }\end{array}$ \\
\hline 8 & 1992 & $\begin{array}{l}2 \text { eggs in nest protected with a } \\
\text { single-nest exclosure; } 2 \text { chicks hatched } \\
\text { and } 1 \text { was confirmed to have fledged. }\end{array}$ \\
\hline 9 & 1992 & $\begin{array}{l}2 \text { eggs in nest protected with a } \\
\text { single-nest exclosure; destroyed by high } \\
\text { winds and blowing sand. }\end{array}$ \\
\hline 10 & 1992 & $\begin{array}{l}2 \text { eggs in nest (located } 2 \mathrm{~km} \text { inland) } \\
\text { protected with a single-nest exclosure; } \\
\text { disrupted by high winds - } 1 \text { egg was } \\
\text { destroyed by off-highway vehicle traffic } \\
\text { after it was apparently blown } 50 \mathrm{~m} \text { from } \\
\text { the nest. }\end{array}$ \\
\hline
\end{tabular}


Nesting behaviors such as nest exchanges, food exchanges, incubation and roosting appeared to be unaffected by the presence of the exclosure. I found no evidence, such as tracks or additional loss of nests, that suggested exclosures increased predation of nests by gulls (Larus spp,) or coyotes (Canis latrans) which were often seen in the area. Four nests for which exclosures were built were destroyed by blowing sand during periods of exceptionally high winds. Six chicks were successfully hatched from the 3 remaining nests, of which $3-5$ birds fledged. 


\section{DISCUSSION}

Small single-nest exclosures were used effectively to protect nests from the impacts of OHV traffic at this site. Nesting failures were attributed primarily to high winds and blowing sand (Table 1).

Least Terns typically produce 2 eggs over a period of 2

or 3 days. Egg-laying was often followed by a period of 6-24 hours when the adult birds were absent from the nest, after which the pair began incubation. The risk of nest abandonment, resulting from construction of the exclosures, appeared to have been reduced by delaying construction until the adult birds began incubating the eggs.

The successful fledging of chicks in an area where OHV activity is intense suggests that use of this type of exclosure would be highly successful at other sites where OHV recreation has impacted Least Tern nesting (Blodget 1978, Caravacho 1989). Furthermore, a modification of the basic design may provide protection for nests and chicks from a variety of other impacts, such as predation.

In addition to the use of exclosures I identified suitable nesting habitat outside the OHV riding area. In the future I plan to use decoys to encourage nesting in these undisturbed areas reducing the need for continuation of intensive management of the colony. 
Conservation and management of California Least Terns as an endangered species has resulted in an increase in the overall population from about 600 to over 1900 breeding pairs during the past 20 years (Massey 1992, USFWS 1980). As the population expands, colonization of new sites will continue. The use of single-nest exclosures can provide managers with an effective means for protecting small nesting colonies until long-term conservation and management strategies can be developed. 


\section{IITERATURE CITED}

ATWOOD, J.L., D.E. MINSKY. 1983. Least Tern Eoraging Ecology at Three Major California Breeding Colonies. Western Birds 14:57-72. 1983 .

BENDER, K. 1974a. California Least Tern census and nesting survey, 1973. Calif. Dept. of Fish and Game, Special Wildlife Investigations, Project $W-54-R$, Progress Report, Job II-II, 7 pp. plus appendix.

. 1974b. California Least Tern population and nesting survey, 1974. Calif. Dept. of Fish \& Game, Nongame Wildlife Investigations, Project W-54-R, Einal Report, Job II.5.1, 5 pp. plus appendix.

BLODGET B.G. 1978. The effect of off-road vehicles on least terns and other shorebirds. National Park Service, Cooperative Research Unit. 79 pp.

BURGER J. 1989. Least Tern populations in coastal New Jersey: Monitoring and management of a regionally endangered species. J. Coastal Res. 5:801-811.

CARVACHO A., R. RIOS, C. LEON, A. ESCOFET. 1989. Sterna antillarum en el Golfo de California: Observaciones sobre una colonia reproductora en una zona vulnerable al impacto turistico. The Southwestern Naturalist. 34:124-130.

GOCHFIELD M. 1983. Colony site selection by Least Terns: Physical attributes of sites. Colonial Waterbirds. $6: 205-213$.

GRINNEL, J. 1928. A distributional summation of the ornithology of lower California. Univ. California Publ. 2001. 32:1-300.

MASSEY, B.W. 1992. California Least Tern Field Study 1992 Breeding Season. State of California, The Resources Agency Dept. of Eish and Game.

MASSEY, B.W. 1975. California Least Tern Census and Nesting Survey, 1975. Calif. Dept. of Fish \& Game (Nongame Wildife Investigations) and the U.S. Fish and Wildlife Service (Kern Pixley N.W.R. - Endangered Species Program), $5 \mathrm{pp}$. plus appendix. 
RIMMER D.W. AND R.D. DEBLINGER. 1990. Use of predator exclosures to protect Piping Plover nests. Field ornithol. 61:21?-223.

U. S. FISH AND WIDLIFE SERVICE. 1980. California Least Tern Recovery Plan. Prepared by the U.S. Fish and Wildlife Service, Region 1, Portland, Oregon, in cooperation with the recovery team. 